\title{
The Electrical Characterization Effect of Insulator Layer between Semiconductor and Metal
}

\author{
İkram ORAK ${ }^{1,2}$, Adem KOÇYİĞİT ${ }^{3}$
}

\begin{abstract}
Metal-Insulator-semiconductor contacts (MIS) have been studied its importance in electronic and optoelectronic. Their importance comes from its so high dielectric constant, storage layer property and effect of capacitance. For this reason, $\mathrm{Si}_{3} \mathrm{~N}_{4}$ were deposited with PECVD technique on p-type $\mathrm{Si}$ about $5 \mathrm{~nm}$ thickness layers. The thicknesses of $\mathrm{Si}_{3} \mathrm{~N}_{4}$ were measured with an elipsometre and obtained MIS contact with Al contact. It was researched the insulator layer effect on the $\mathrm{Al} / \mathrm{p}$-Si contact. Its electrical characterizations were inquired by use of the forward and reverse bias $I-V, C-V$ and $G-V$ measurements and were seen that the insulator $\mathrm{Si}_{3} \mathrm{~N}_{4}$ layer influenced characterizations of the contact. Effect of the interface states $\left(N_{s s}\right)$, the series resistance $\left(R_{s}\right)$ and the other some electrical parameters were investigated by calculating from $I-V$ and $C-V$ measurements. It was observed that from the $C-V$ characterizations at $500 \mathrm{kHz}$ dual, contact behaved similarly memristor structure.
\end{abstract}

Keywords: $\mathrm{Al} / \mathrm{Si}_{3} \mathrm{~N}_{4} / \mathrm{p}$-Si, capacitance behavior, metal-insulator-semiconductor structure, Schottky diode

\section{Metal ve Yarıiletken Arasındaki Yalıtkan Tabakanın Elektriksel karakterizasyon Etkisi}

ÖZET: Metal-yalıtkan-yarilietken (MIS) aygıtlar elektronik ve optoelektronikteki önemlerinden dolayı çalışılmaktadır. Bu önem aygıtların yüksek dielektrik sabitine, depolama tabakası ve kapasitans özelliklerine sahip olmalarından kaynaklanmaktadır. Bu yüzden $\mathrm{Si}_{3} \mathrm{~N}_{4}$ tabakası p-tipi $\mathrm{Si}$ üzerine PECVD tekniği kullanılarak büyütülmüş, kalınlığ elipsometre ile $5 \mathrm{~nm}$ olarak ölçülmüştür ve $\mathrm{Al}$ kontak sayesinde MIS yapısı elde edilmiştir. Elde edilen $\mathrm{Al} / \mathrm{p}$-Si yapısı üzerine $\mathrm{Si}_{3} \mathrm{~N}_{4}$ tabakasının etkisi araştırılmıştır. Bunun için aygıtın elektrik karakterizasyonları ileri ve ters beslem $I-V, C-V$ ve $G-V$ ölçümleriyle yapılmış ve yalıtkan $\mathrm{Si}_{3} \mathrm{~N}_{4}$ tabakanın diyot özelliklerini oldukça etkilediği görülmüştür. Ara yüzey halleri $\left(N_{s s}\right)$, seri direnç $\left(R_{s}\right)$ ve diğer bazı elektriksel parametrelerin aygıt üzerine etkileri $I-V$ ve $C-V$ ölçümlerinden hesaplanarak araştırılmıştır. $C$ - $V$ ölçümlerinden aygıtın memristör bir yapı gibi davrandiğı tespit edilmiştir.

Anahtar Kelimeler: $\mathrm{Al} / \mathrm{Si}_{3} \mathrm{~N}_{4} / \mathrm{p}$-Si, kapasitör özelliği, metal-yalıtkan-yariiletken yapılar, Schottky diyot

\footnotetext{
Bingöl Üniversitesi, Sağlık Hizmetleri Meslek Yüksekokulu, Tibbi Hizmetler ve Teknikler Bölümü, Bingöl, Türkiye

Bingöl Üniversitesi, Fen Edebiyat Fakültesi, Fizik Bölümü, Bingöl, Türkiye

Iğdır Üniversitesi, Mühendislik Fakültesi, Elektrik Elektronik Mühendisliği Bölümü, Iğdır, Türkiye

Sorumlu Yazar/Corresponding Author: Adem KOÇYIĞíT, adem.kocyigit@igdir.edu.tr
} 


\section{INTRODUCTION}

Metal-semiconductor contacts (Schottky diodes) are fundamental and mostly employed in technology e.g. rectifiers, inverters, freewheeling and polarity protection diodes (Sharma et al., 2004; Rajesh and Menon 2007; Güllü and Türüt, 2010; Karataş et al., 2013). From past to present, there has been increasing attention of these contacts because they have used in optic and electronic (Markyart, 2000; Sze and Kwok, 2007; Tatar et al., 2009; Orak et al., 2014). Current conduction mechanism and barrier height forming in these contacts are depend on several parameters such as interfacial layer, series resistances, doping acceptor/ donor concentration of atoms, interface states density, the thickness and homogeneity of barrier height and interfacial layer, sample temperature and applied bias voltage. But the performance and quality of these contacts can be changed or improved by using interfacial insulator layers (Bilkan et al., 2015). If an insulator sheet for instance $\mathrm{TiO}_{2}, \mathrm{SrTiO}_{3}, \mathrm{SiO}_{2}, \mathrm{SnO}_{2}$ and $\mathrm{Si}_{3} \mathrm{~N}_{4}$ is inserted between semiconductor and metal, the metal semiconductor structures change a metaloxide-semiconductor (MOS) structure (Türüt et al., 2015) ( $\geq 100 \AA)$ or metal-insulator-semiconductor (MIS) (Zeyrek et al., 2006) $(\leq 100 \AA)$ based on the thickness of insulator. Presence of some insulator layer induces deviation from the ideal property which could be detected the $C-V$ and $G / w-V$ measurements of metal semiconductor contacts (Gökçen et al., 2012). The important characteristic of insulator layer at the MIS structure has a dielectric property which is resemble a capacitor. If insulator layer between semiconductor and metal is very thin ( $30 \AA)$, electrical parameters of this structure could be specified by $I-V$ and $C-V$ characterizations. But the existence of more thickness insulator layer at the interface, $I-V$ characteristics cannot be measured (Sönmezoğlu and Akın, 2011).

In the present study, $\mathrm{Al} / \mathrm{Si}_{3} \mathrm{~N}_{4} / \mathrm{p}$ type $\mathrm{Si}$ contact has been investigated according to insulator layer effect at room temperature because of understanding performance and quality of this contact.

\section{MATERIALS AND METHODS}

p-type Si wafer which was polished and cleaned used for the deposition of the $\mathrm{Al} / \mathrm{Si}_{3} \mathrm{~N}_{4} / \mathrm{p}$ type $\mathrm{Si}$ heterojunction has (100) orientation and $7.3 \times 10^{15}$ $\mathrm{cm}^{-3}$ carrier concentration according to manufactures specifications. The wafer was degreased consecutively in acetone and isopropyl alcohol with ultrasonic mixer for $5 \mathrm{~min}$. Before ohmic contact, the wafer p-type Si was cut into pieces of $1.0 \mathrm{~cm}$ length by $1.0 \mathrm{~cm}$ breadth. The degreased wafer was etched with $\mathrm{HF}: \mathrm{H}_{2} \mathrm{O}(1: 10)$ for 30 second to take out the surface damages and undesirable impurities. Aluminum was vaporized (thermal) on another side of the p-type $\mathrm{Si}$ for the ohmic contact and the p-Si/Al was puddled at $450{ }^{\circ} \mathrm{C}$ for 3 minute in $\mathrm{N}_{2}$ ambience. The insulator layers have been formed PECVD technique on p-type Si nearly $5 \mathrm{~nm}$ thicknesses. (The ratio of $\mathrm{Si}_{3} \mathrm{~N}_{4}\left(\mathrm{SiH}_{4}: \mathrm{NH}_{3},(185: 45\right.$ sccm)) The schematic diagram of contact could be seen in Figure 1. The Al contacts have been formed by thermal vapor method as points with diameter of around $1.0 \mathrm{~mm}$ on the front surface of the $\mathrm{p}$-Si. The thickness of metal coating was designated with a quartz screen positioned in close intimacy to the Si. The $I-V$ and $C$ - $V$ measurements of the diode were performed by use of a Keithley 2400 Picoammeter/Voltage Apparatus and HP 4192 A LF Impedance Analyzer.

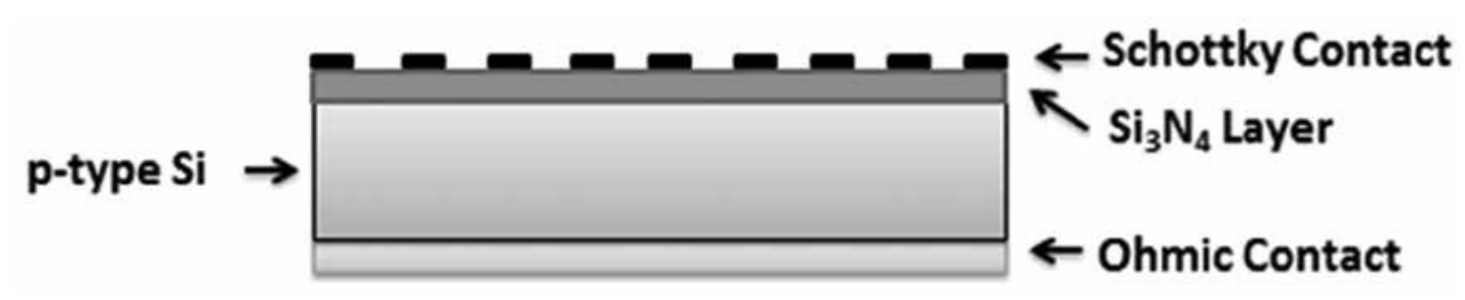

Figure 1. Schematic diagram of $\mathrm{Al} / \mathrm{Si}_{3} \mathrm{~N}_{4} / \mathrm{p}-\mathrm{Si}$ Schottky contact

\section{RESULTS AND DISCUSSION}

It has been shown the typical semi-logarithmic
$I-V$ characteristics of the $\mathrm{Al} / \mathrm{Si}_{3} \mathrm{~N}_{4} / \mathrm{p}-\mathrm{Si}$ structure in Figure 2. 


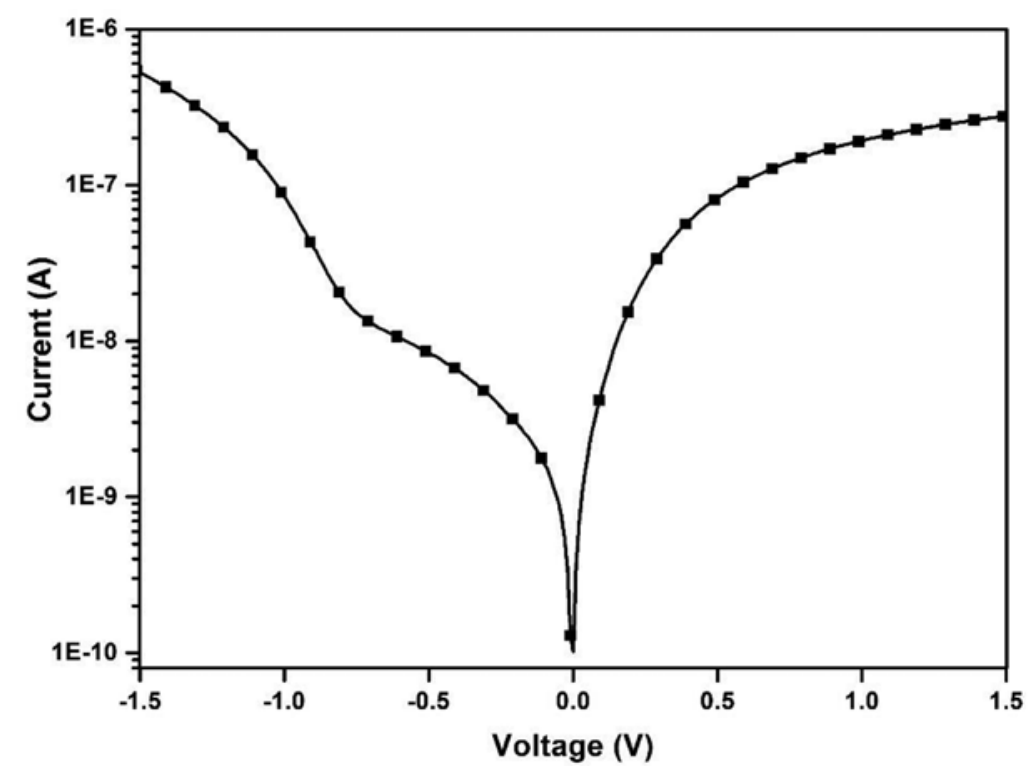

Figure 2. $\ln I-V$ characteristic of $\mathrm{Al} / \mathrm{Si}_{3} \mathrm{~N}_{4} / \mathrm{p}-\mathrm{Si}$ in dark at room temperature

According to this figure, contact has a rectifying behavior under dark at room temperature. Important diode parameters i.e ideality factor and barrier height could be gotten from this graph. The ideality factor (n) could be obtained from the gradient of the linear region of the forward bias $I-V$ plot and barrier height $\left(\Phi_{b}\right)$ could be found the current axis intercept of this linear. The Current is given by the equation (El-Nahass et al., 2011);

$$
I=I_{0} \exp \left(\frac{q V}{n k T}\right)\left[1-\exp \left(\frac{q V}{n k T}\right)\right]
$$

where $I_{0}$ is the saturation current which is obtained from the intercept of $\ln I$ vs $V$ plot at $V=0$, written as

$$
I_{0}=A A^{*} T^{2} \exp \left(-\frac{q \Phi_{b}}{K T}\right)
$$

where $q$ is the electronic charge, $V$ is the applied voltage, $K$ is Boltzmann's constant, $T$ is the temperature $(=300 \mathrm{~K}), A^{*}$ is the effective Richardson constant $\left(A^{*}=32 \mathrm{~A} \mathrm{~cm}^{-2} \mathrm{~K}^{-2}\right.$ for p-type $\left.\mathrm{Si}\right), A$ is the area of diode $\left(=7.85 \times 10^{-3} \mathrm{~cm}^{2}\right), \Phi_{b}$ is the Schottky barrier height at zero bias and $n$ is the ideality factor. The ideality factor (for $V \geq 3 \mathrm{kT} / \mathrm{q}$ ) and barrier height specified from the forward bias $\ln I-V$ characteristics by use of the Equations (1) and (2)

$$
\begin{gathered}
n=\frac{q}{k T}\left(\frac{d V}{d \ln I}\right) \\
\text { and }
\end{gathered}
$$

$$
\Phi_{b}=\frac{k T}{q} \ln \left(\frac{A^{*} A T^{2}}{I_{0}}\right)
$$

In respect of Equations (3) and (4), the worth of the ideality factor $(n)$ and the barrier height $\left(\Phi_{b}\right)$ of $\mathrm{Al} / \mathrm{Si}_{3} \mathrm{~N}_{4} / \mathrm{p}$-Si Contact were accounted as 1.34 and $0.73 \mathrm{eV}$, respectively. These results have been given in Table 1, also. The worth of ideality factor has higher than from unity which is suggesting Schottky contact is not ideal. If $n$ equals unity, pure thermionic emission occurs but $n$ is usually greater than one. This high ideality factor can be ascribed to several influences i.e tunnelling process (Lee et al., 2010) and irregular scatter of the interfacial charges (Demircioğlu et al., 2011), image-force effect (Sharma and Tewari, 2011), interface states (Orak et al., 2015), barrier inhomogeneity (Roul et al., 2015) and series resistance (Korucu and Duman, 2015). High value of $n$ verify the existence of an insulator sheet between semiconductor and metal, also (Nasim and Bhatt, 2013). In here, beside the insulator layer of $\mathrm{Si}_{3} \mathrm{~N}_{4}$, a little amount of $\mathrm{SiO}_{2}$ may be formed.

The barrier height $\left(\Phi_{b}\right)$ and series resistance $\left(R_{s}\right)$ could be accounted also by Norde method (Güllü et 
al., 2012) and the Cheung's functions (Cheung and Cheung, 1986). If the Schottky contact has series resistance, the clear amount current of the contact is because of thermionic emission and could be stated as for Cheung's functions (Karataş et al., 2013);

$I=I_{0} \exp \left(-\frac{q\left(V-I R_{s}\right.}{n k T}\right)$

where $I R_{s}$ term is the voltage descent owing to series resistance. The worth of the series resistance can be calculated from the below equations: $\frac{d V}{d(\ln I)}=I R_{s}+n \frac{k T}{q}$

$H(I)=V-n\left(\frac{k T}{q}\right) \ln \left(\frac{I}{A A^{*} T^{2}}\right)$

where $H(I)$ could be written as:

$H(I)=I R_{S}+n \Phi_{b}$

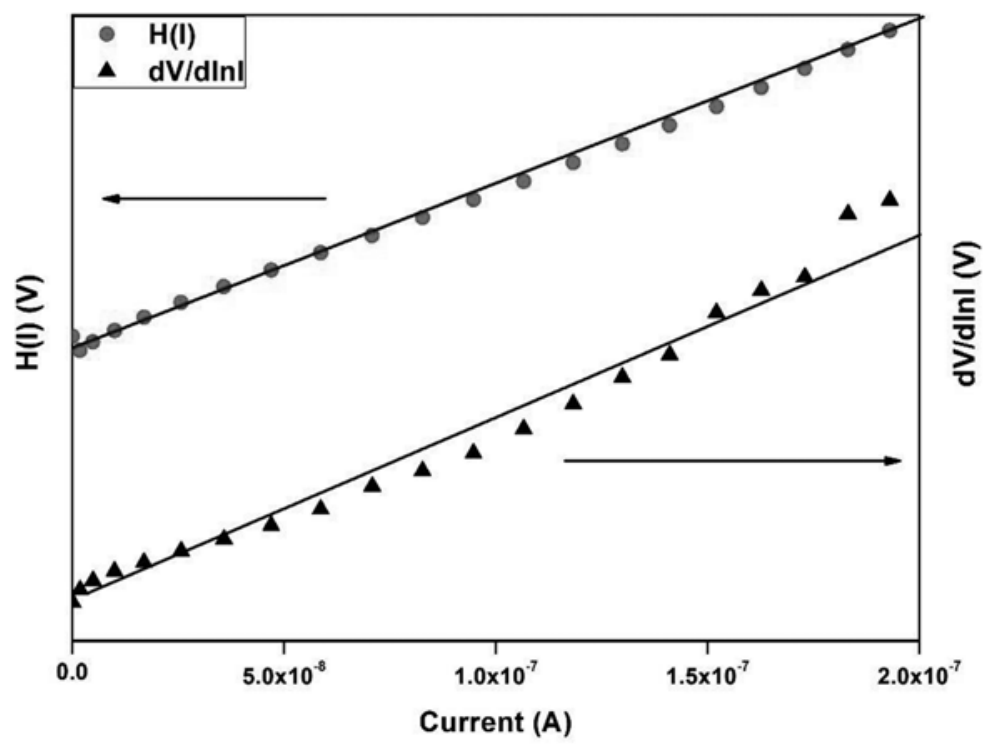

Figure 3. dv/dln $I-I$ and $H(I)-I$ graphs of $\mathrm{Al} / \mathrm{Si}_{3} \mathrm{~N}_{4} / \mathrm{p}-\mathrm{Si}$ Schottky contact

Equations (6) and (8) give a straight for the data of decreasing curvature region of the forward bias $I-V$ plot. For this reason, the plot of $d V / d(\ln I)$ vs $I$ will be linear and obtain $R_{s}$ as the slope and $n k T / q$ as the $y$-axis intercept from Equation (6). Graph of $H(I)$ vs $I$ according to Equation (8) will be also linear and $y$-axis intercept will equal to $n \Phi_{b}$. In here, $n$ worth is obtained from graphs of $d V / d(\ln I)$ vs $I$ and so, $\Phi_{b}$ is accounted easily. The slope of $H(I)$ vs $I$ also gives a second designation of $R_{s}$ which could be indicated to control the coherency of Cheung method. The graphs of $d V / d(\ln I)$ vs $I$ and $H(I)$ vs $I$ have been attained the forward bias $I-V$ measurement of the $\mathrm{Al} / \mathrm{Si}_{3} \mathrm{~N}_{4} / \mathrm{p}-\mathrm{Si}$ contact and given in Figure 3. The values of $n, \Phi_{b}, R_{s}$ $(d V / d(\ln I))$ and $R_{s}(H(I))$ have been accounted as 1.07 , $0.81 \mathrm{eV}, 4.13 \mathrm{~K} \Omega$ and $4.55 \mathrm{~K} \Omega$, respectively. These obtained results have been also given in Table 1 and indicated the accuracy of Cheung's method. There is a small variation between the worth of the ideality factor acquired from the decreasing curvature region of the forward bias $I-V$ plot and the linear region of the same characteristics. This variation could be ascribed to the presence of influences i.e. the bias dependency of the Schottky barrier height and the series resistance, 
charge of the interface states with bias in this concave region of the $I-V$ measurement and according to the voltage descent the interfacial layer (Demircioğlu et al.,
2011). It is observed that the worth of $n$ attained from the forward bias $\ln I-V$ plot is agreeing with that of the $d V / d(\ln l)-I$ curves (Tatar et al., 2009).

Table 1. The experimental diode parameters calculated from $I-V$ measurements for $\mathrm{Al} / \mathrm{Si}_{3} \mathrm{~N}_{4} / \mathrm{p}-\mathrm{Si}$ contact.

\begin{tabular}{ccccccccc}
\hline $\boldsymbol{n}(\boldsymbol{I}-\boldsymbol{V})$ & $\boldsymbol{n}$ Cheung & $\begin{array}{c}\Phi_{b} \\
(\boldsymbol{I}-\boldsymbol{V}) \\
(\mathrm{eV})\end{array}$ & $\begin{array}{c}\Phi_{b} \\
\mathbf{C h e u n g} \\
(\mathrm{eV})\end{array}$ & $\begin{array}{c}\Phi_{b} \\
\text { Norde } \\
(\mathrm{eV})\end{array}$ & $\begin{array}{c}\Phi_{b} \\
(\boldsymbol{C}-\boldsymbol{V}) \\
(\mathrm{eV})\end{array}$ & $\begin{array}{c}\boldsymbol{R}_{\boldsymbol{s}} \text { Cheung } \\
(\mathrm{k} \boldsymbol{\Omega} \\
(H(I)))\end{array}$ & $\begin{array}{c}\boldsymbol{R}_{\boldsymbol{s}} \text { Cheung } \\
((\mathrm{k} \boldsymbol{\Omega} \\
(d \ln (I))\end{array}$ & $\begin{array}{c}\boldsymbol{R}_{\boldsymbol{s}} \\
\text { Norde } \\
(\mathrm{k} \Omega)\end{array}$ \\
\hline 1.34 & 1.07 & 0.73 & 0.81 & 0.81 & 0.69 & 4.55 & 4.13 & 12.1 \\
\hline
\end{tabular}

Norde method can be used as another technique for calculating of the series resistance especially for the high series resistance. The following equation has been identified in the changed Norde method (Karataş et al., 2013):

$F(V)=\frac{V}{\gamma}-\frac{k T}{q} \ln \left(\frac{I(V)}{A A^{*} T^{2}}\right)$

where $\gamma$ is an integer $(\gamma>n)$. Ideality factor is used from thermoionic emission theory results and $I(V)$ is current acquired from the $I-V$ curve. Firstly, using plot of the $F(V)$ vs $V$

$\Phi_{b}=F\left(V_{0}\right)+\left[\frac{V_{0}}{\gamma}-\frac{k T}{q}\right]$
$\Phi_{b}$ can be obtained from Equation (10), where $F\left(V_{0}\right)$ is the minimum point of $F(V)$ and $V_{0}$ is the related voltage.

$$
R_{S}=\frac{\gamma-n}{I} \frac{k T}{q}
$$

From the $F(V)-V$ plot (shown in Figure 4) by use of $F\left(V_{0}\right)=0.815 \mathrm{~V}$ and $V_{0}=0.044 \mathrm{~V}$ values, $\Phi_{b}$ and $R_{s}$ of the $\mathrm{Al} / \mathrm{Si}_{3} \mathrm{~N}_{4} / \mathrm{p}-\mathrm{Si}$ contact have been calculated as $0.81 \mathrm{eV}$ and $12.1 \mathrm{k} \Omega$, respectively.

The results of $\Phi_{b}$ and $R_{s}$ obtained from Norde method has been given in Table 1. The barrier height values are same and there is relative difference between series resistance values obtained from Cheung and Norde methods.

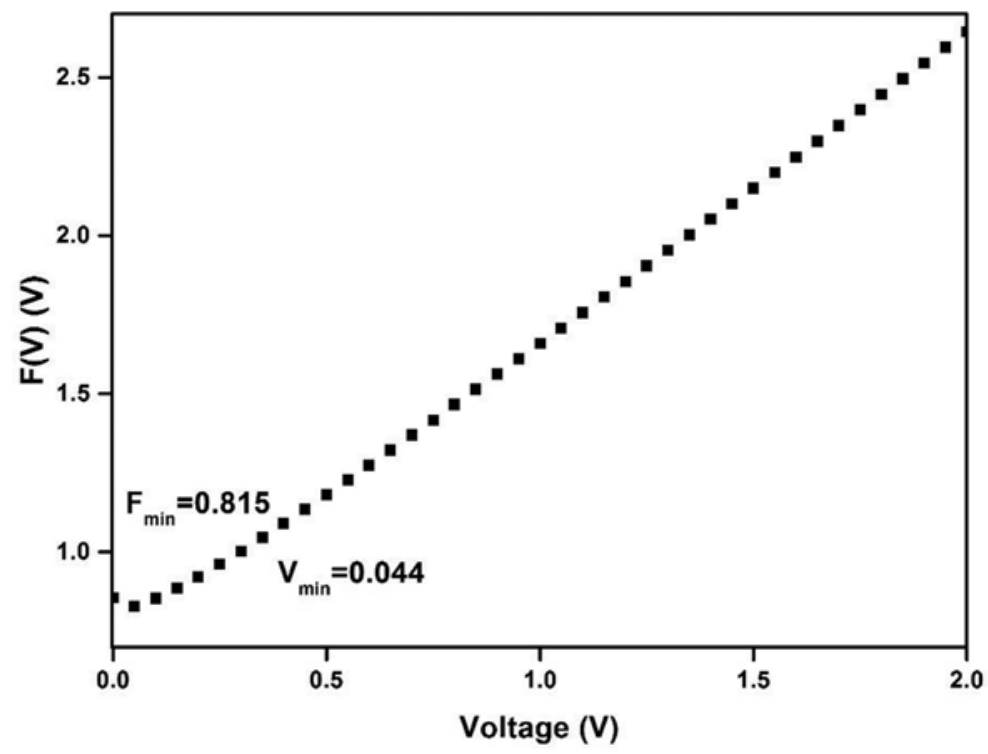

Figure 4. $F(V)$ vs $V$ graph of $\mathrm{Al} / \mathrm{Si}_{3} \mathrm{~N}_{4} / \mathrm{p}-\mathrm{Si}$ contact 
$\ln I-V$ plot which have a non-linearity part at high forward bias voltages shows a continuum of $N_{s s}$ in balance with semiconductor. For diode, the energy density scatter condition of the $N_{s s}$ was designated from the forward bias $I-V$ by considering efficient barrier height $\left(\Phi_{e}\right)$, ideality factor $n(V)$ which is depend on the voltage and $R_{s}$. The $\Phi_{e}$ can be written as following equation (Bilkan et al., 2015):

$\Phi_{e}=\Phi_{b}+(1-1 / n(V))\left(V-I R_{s}\right)$

Since the ideality factor of a diode become all time greater than one, it was suggested below formula by Card and Rhoderick (Card and Rhoderick, 1971).

$n(V)=1+\frac{\delta}{\varepsilon_{i}}\left[\frac{\varepsilon_{s}}{W_{d}}+q N_{s s}(V)\right]$

where $W_{d}$ is depletion layer width and $\delta$ is the thickness of the insulator sheet at the interface. $\varepsilon_{i}$ and $\varepsilon_{s}$ are permittivity of interfacial layer and the semiconductor, respectively. For diode, proposed the energy density scatter of $N_{s s}$ can be found from the forward bias $I-V$ data by using voltage dependent of effective barrier height $\left(\Phi_{e}\right)$ and ideality factor $(n(V))$ by which suggested by Card and Rhoderick (Card and Rhoderick, 1971):

$$
\left.N_{s S}(V)=\frac{1}{q}\left[\frac{\varepsilon_{i}}{\delta}(n(V)-1)-\frac{\varepsilon_{s}}{W_{d}}\right)\right]
$$

In addition, for p-type semiconductors, the energy of the $N_{s s}$ as regards the upper of the valance band $\left(E_{v}\right)$ at the semiconductor surface can be accounted as

$E_{s S}-E_{v}=q\left(\Phi_{e}-\left(V-I R_{s}\right)\right)$

where the $I R_{s}$ term is the voltage descent on the $R_{s}$. The energy density distribution profile of $N_{s s}$ with (inset of Figure 5) and without $R_{s}$ that is obtained from the forward-bias $I-V$ has been indicated in Figure 5. It could be observed that the $N_{s s}$ worth with series resistance are lower than those obtained without considering the $R_{s}$. These results advised that the $R_{s}$ value should be considered in definition the energy density scatter of $N_{s s}$ (Bilkan et al., 2015).

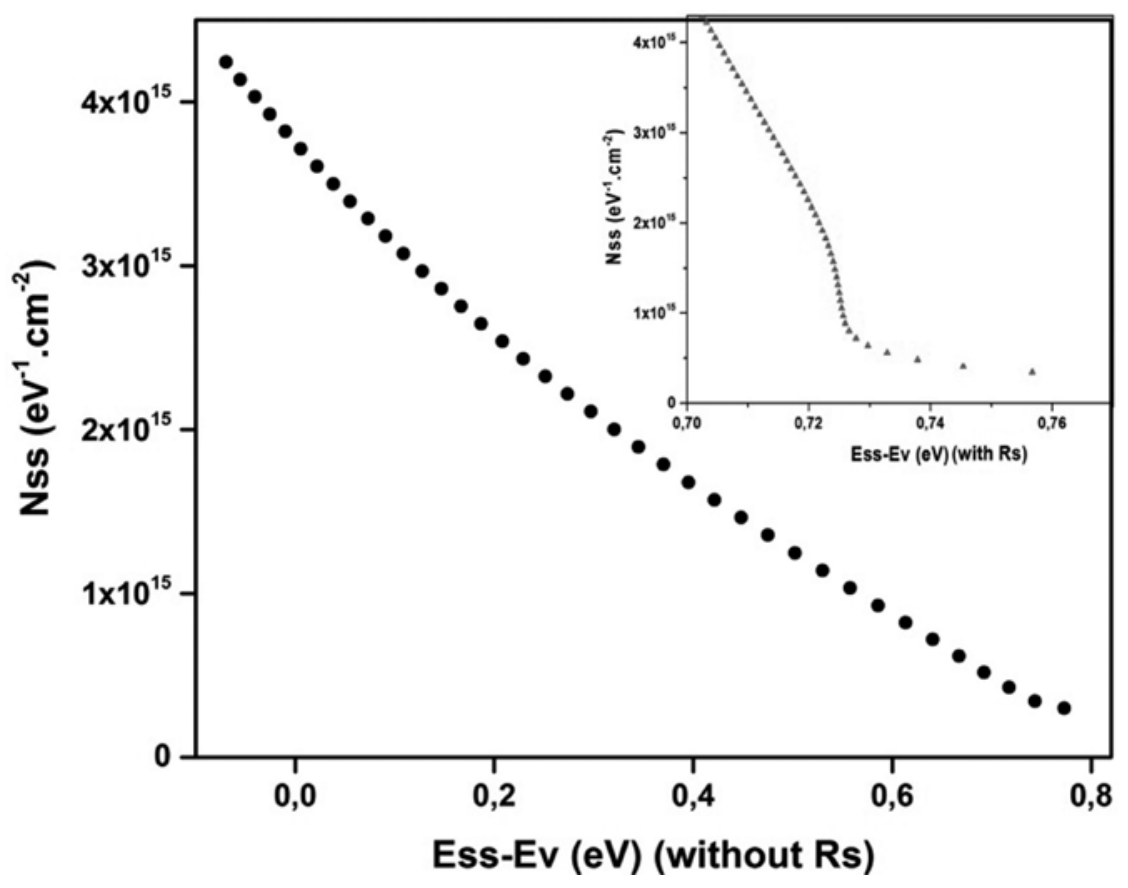

Figure 5. $N_{s s}-\left(E_{s s}-E_{v}\right)$ graphs with $R_{s}$ and without $R_{s}$ 
$C-V$ and $G-V$ graphs could be observed in Figure 6 and 7 , respectively for $\mathrm{Al} / \mathrm{Si}_{3} \mathrm{~N}_{4} / \mathrm{p}-\mathrm{Si}$ contact. The existence of the capacitance peak in the forward bias on $C-V$ graphs was surveyed on MIS contact and attributed to the molecular arrangement of the series resistance and interface states (Bülbül et al., 2006). It has been in Figure 6 that the change in frequency affects the worth and status of $C-V$ peaks. Moreover, the capacitance values have increased with the frequency decreasing. The high capacitance values at low frequencies could be ascribed the existence of the interface states at the $\mathrm{Al} / \mathrm{Si}_{3} \mathrm{~N}_{4} / \mathrm{p}$-Si contact (Ataseven and Tataroğlu, 2013). In other words, charges at the interface states can chase the changing current (ac) signal at low frequencies. However, towards to high frequencies, these charges cannot chase the ac signal and not support to the capacitance (Yahia et al., 2011). But the conductance values have increasing tendency towards to high frequencies. These conclusions could be seen in Figure 6 and 7 for capacitance and conductance, respectively in $\mathrm{Al} / \mathrm{Si}_{3} \mathrm{~N}_{4} / \mathrm{p}$ type $\mathrm{Si}$ junction contact. In here, each $C-V$ plot for different frequency has three regions (accumulation, depletion and inversion) could be seen in Figure 6, with a thinking voltage-axis change towards the reverse bias because of the interface states which is in balance via semiconductor. Similarly, Figure 7 has been indicated the changing of the conductance in the depletion zone for the same frequency alteration, showing the presence of several time-dependent reactions of interface states (Bülbül and Zeyrek, 2006).

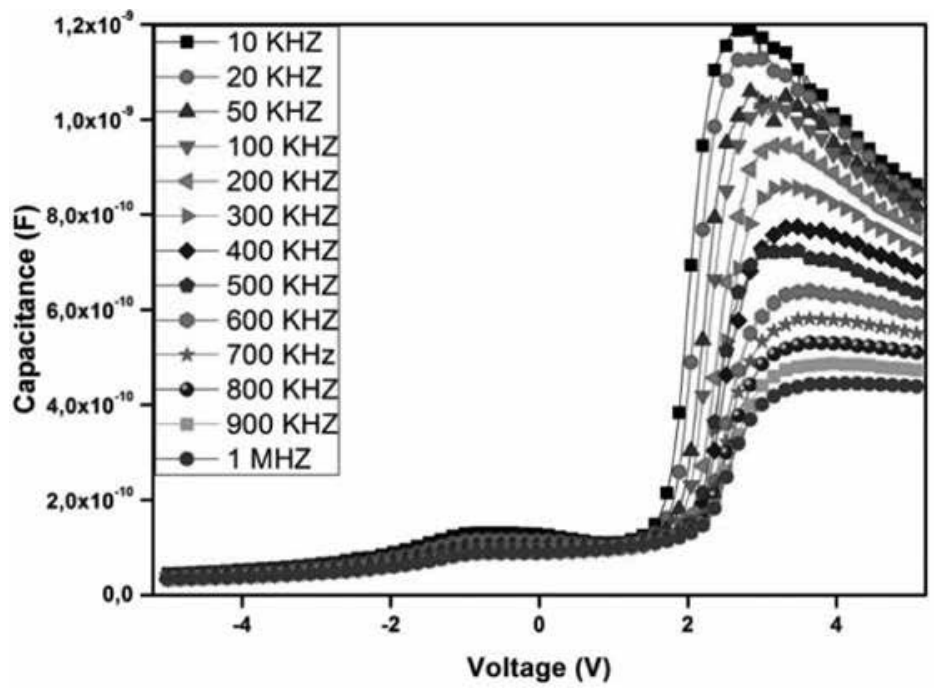

Figure 6. The capacitance-voltage $(C-V)$ characteristic depending frequencies for $\mathrm{Al} / \mathrm{Si}_{3} \mathrm{~N}_{4} / \mathrm{p}$-Si contact

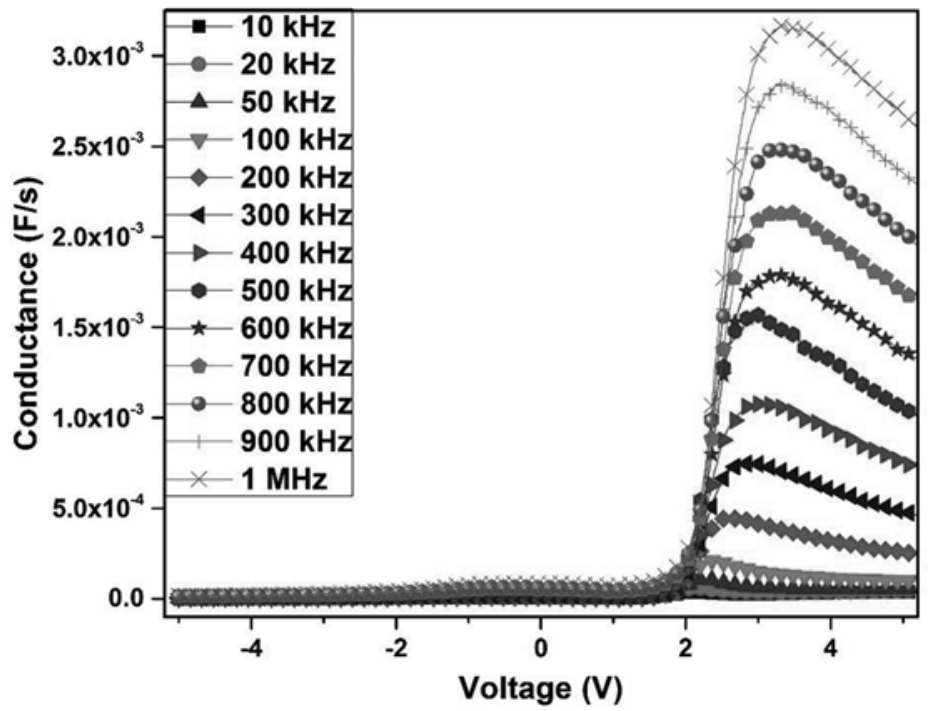

Figure 7. The conductance-voltage $(G-V)$ characteristic depending frequencies for $\mathrm{Al} / \mathrm{Si}_{3} \mathrm{~N}_{4} / \mathrm{p}$-Si contact 
The $C^{-2}-V$ graphs of $\mathrm{Al} / \mathrm{Si}_{3} \mathrm{~N}_{4} / \mathrm{p}$ type $\mathrm{Si}$ junction contact have been shown for various frequencies in Figure 8. It has been seen from this figure, the $C^{-2}-V$ graph shows a straight in extensive voltage interval and the diffusion potential which is given in Table 2 is attained with extrapolation of straight lines to the voltage axis. It is known that intercept and slope voltage of the $C^{-2}-V$ plot is dependent on the density of interface states and interface insulator sheet (Sztkowski and Sieranski, 1992). The $C^{-2}-V$ graphs point out that the ac signal could not been follow by interface states and inversion layer charge in the depletion region, particularly in the accumulation and strong inversion (Bülbül and Zeyrek, 2006).

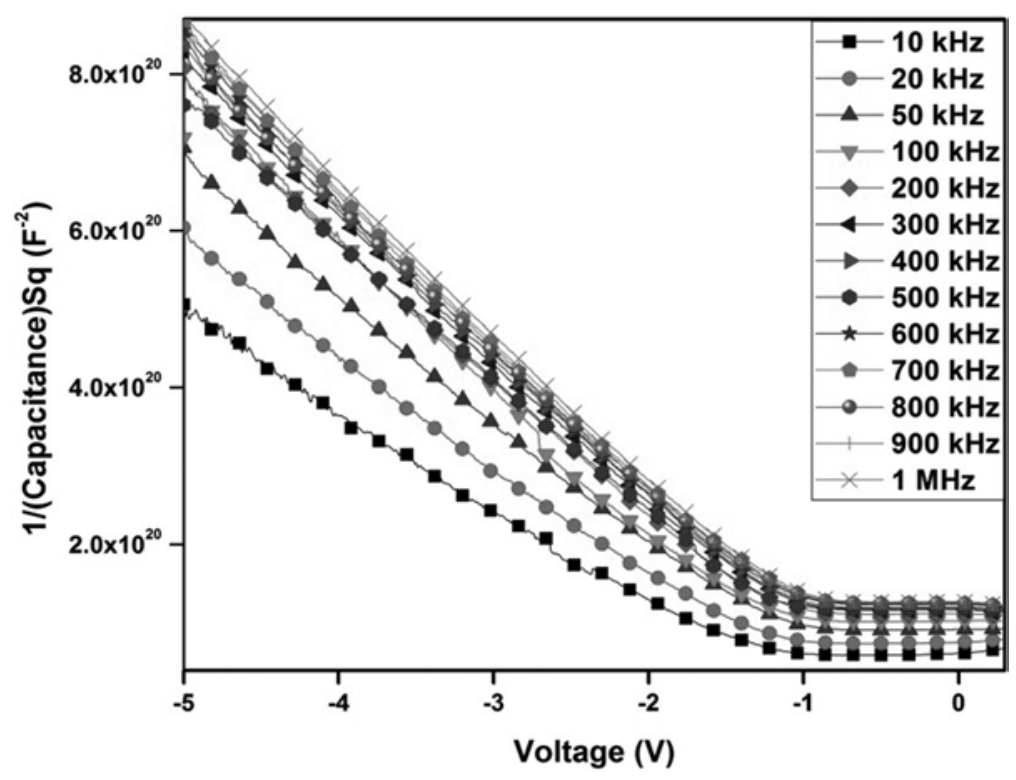

Figure 8. The $C^{-2}-V$ plot of different frequencies $\mathrm{Al} / \mathrm{Si}_{3} \mathrm{~N}_{4} / \mathrm{p}$ type Si contact

The other some important electrical parameters of diode such as, Fermi energy level $\left(E_{F}\right)$, intercept voltage $V_{i,}$ the width of the depletion region $\left(W_{d}\right)$, the concentration of acceptor atoms $\left(N_{a}\right)$, the image force barrier lowering $\left(\Delta \Phi_{b}\right)$ and the values of barrier heights of $\Phi_{b}$ were calculated the capacitance-voltage $(C-V)$ measurements at $10 \mathrm{kHz}$ to $1 \mathrm{MHz}$ frequencies and all of them given in Table 2 for obtaining diode properties.

Table 2. The various parameters of $\mathrm{Al} / \mathrm{Si}_{3} \mathrm{~N}_{4} / \mathrm{p}$-Si MIS contact obtained from $C-V$ in the different frequencies

\begin{tabular}{cccccccc}
\hline $\boldsymbol{f}(\mathbf{k H z})$ & $\boldsymbol{N}_{\boldsymbol{A}}\left(\mathbf{1 0}^{\mathbf{1 5}} \mathbf{c m}^{-\mathbf{3}}\right)$ & $\boldsymbol{V}_{\boldsymbol{d}}(\mathbf{V})$ & $\boldsymbol{E}_{\boldsymbol{F}}(\mathbf{e V})$ & $\Delta \boldsymbol{\Phi}_{\boldsymbol{b}}(\mathbf{e V})$ & $\boldsymbol{\Phi}_{\boldsymbol{b}}(\mathbf{e V})$ & $\boldsymbol{W}_{\boldsymbol{d}}\left(\mathbf{1 0 ^ { - 5 }} \mathbf{c m}\right)$ & $\boldsymbol{E}_{\boldsymbol{m}}\left(\mathbf{1 0 ^ { 4 }}\right)\left(\mathbf{V} \mathbf{c m}^{-\mathbf{1}}\right)$ \\
\hline 10 & 1.645 & 0.889 & 0.178 & 0.0158 & 1.051 & 8.435 & 2.077 \\
20 & 1.404 & 0.944 & 0.189 & 0.0157 & 1.117 & 9.407 & 2.035 \\
50 & 1.259 & 0.736 & 0.192 & 0.0143 & 0.914 & 8.807 & 1.701 \\
100 & 1.063 & 0.804 & 0.196 & 0.0141 & 0.986 & 9.979 & 1.637 \\
200 & 1.129 & 0.714 & 0.195 & 0.0139 & 0.895 & 9.167 & 1.586 \\
300 & 1.075 & 0.633 & 0.196 & 0.0133 & 0.816 & 8.805 & 1.467 \\
400 & 1.079 & 0.482 & 0.196 & 0.0125 & 0.666 & 7.705 & 1.285 \\
500 & 1.129 & 0.623 & 0.195 & 0.0134 & 0.804 & 8.563 & 1.485 \\
600 & 1.056 & 0.605 & 0.196 & 0.0131 & 0.788 & 8.728 & 1.416 \\
700 & 1.040 & 0.555 & 0.197 & 0.0128 & 0.739 & 8.382 & 1.355 \\
800 & 1.097 & 0.578 & 0.195 & 0.0131 & 0.761 & 8.367 & 1.412 \\
900 & 1.040 & 0.542 & 0.197 & 0.0127 & 0.726 & 8.284 & 1.340 \\
1000 & 1.039 & 0.508 & 0.197 & 0.0125 & 0.693 & 8.063 & 1.292 \\
\hline
\end{tabular}

Capacitance of depletion layer can be written as (Sze, 1981). 
$C^{-2}=\frac{2\left(V_{R}+V_{i}\right)}{q \varepsilon_{S} N_{a} A^{2}}$

here, $V_{R}$ is the reverse bias voltage, $N_{a}$ is the acceptor concentration of doping element and $V_{i}$ is the intercept voltage at zero bias and can be acquired by means of extrapolation of the $C^{-2}-V$ plot to the voltage axis. Accounted $N_{a}$ values have been given in Table 2 for different frequencies. From $V_{i}$ values, the diffusion potentials $\left(V_{d}\right)$ at zero bias can be found by use of below equation;

$V_{d}=V_{i}+\frac{K T}{q}$

The depletion layer widths $\left(W_{d}\right)$ of the contact were also accounted from $C^{-2}-V$ plots at for different frequencies below equation;

$W_{d}=\left(\left(2 \varepsilon_{s} \varepsilon_{0} V_{d}\right) / q N_{a}\right)^{1 / 2}$

The Fermi energy level could be calculated as

$E_{F}=\frac{K T}{q} \operatorname{Ln}\left(\frac{N_{v}}{N_{a}}\right)$
With

$N_{v}=4.82 \times 10^{15} T^{3 / 2}\left(\frac{m_{h}^{*}}{m_{0}}\right)^{3 / 2}$

where $N_{v}$ is the efficient density of states in Si valance band and given as $1.04 \times 10^{19} \mathrm{~cm}^{-3}, m_{h}{ }^{*}=0.16 m_{0}$ is the effective mass of holes and $m_{0}$ is the rest mass of the electron. $\Delta \Phi_{b}$ is the image force barrier lowering and is given by

$\Delta \Phi_{b}=\left[\frac{q E_{m}}{4 \pi \varepsilon_{s} \varepsilon_{0}}\right]^{1 / 2}$

where $E_{m}$ is the maximum electric field and calculated with

$E_{m}=\left[\frac{2 q N_{a} V_{i}}{\varepsilon_{S} \varepsilon_{0}}\right]^{1 / 2}$

After accounting of worth of $V_{d}, E_{F}$ and $\Delta \Phi_{b}$, the values of barrier heights $\Phi_{b}(C-V)$ could be obtained from below relation;

$\Phi_{b}(C-V)=V_{d}+E_{F}-\Delta \Phi_{b}$

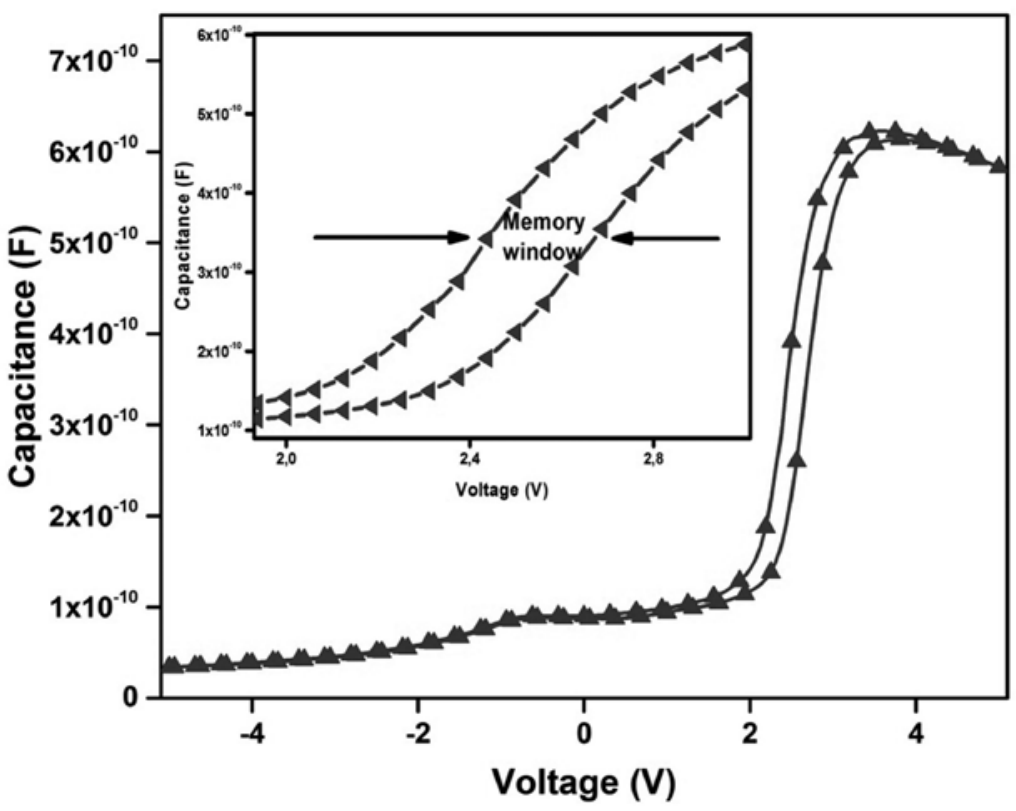

Figure 9. The capacitance-voltage characterization of $\mathrm{Al} / \mathrm{Si}_{3} \mathrm{~N}_{4} / \mathrm{p}$ type $\mathrm{Si}$ and Memory window graph at $500 \mathrm{kHz}$ frequency 
The issue of memristor is new and general because it has low power and nonvolatile operation, variety of physical mechanisms and potentially high density, placing advanced components of future computing systems (Orak et al., 2015). $\mathrm{Si}_{3} \mathrm{~N}_{4}$ is commonly used memory contacts for memristive characterizations. As can be seen in Figure 9, The $\mathrm{Al} / \mathrm{Si}_{3} \mathrm{~N}_{4} / \mathrm{p}$ type $\mathrm{Si}$ has a memory window owing to $\mathrm{Si}_{3} \mathrm{~N}_{4}$ at $500 \mathrm{kHz}$ at $2 \mathrm{~V}$ to $3 \mathrm{~V}$ bias voltages. There is a near parallel shift in measured $C-V$ characteristics. According to this graph, the contact can be used and improved some memory device applications.

\section{CONCLUSION}

The $\mathrm{Al} / \mathrm{Si}_{3} \mathrm{~N}_{4} / \mathrm{p}$-Si contact (MIS) have been investigated its importance in electronic applications, especially capacitance behaviors. For this reason, 5 $\mathrm{nm} \mathrm{Si} \mathrm{N}_{4}$ layers were doped with PECVD technique on p-type $\mathrm{Si}$ and obtained MIS contact with $\mathrm{Al}$ contact. It was researched the insulator layer effect on the $\mathrm{Al} / \mathrm{p}$ $\mathrm{Si}$ contact properties. It was investigated electrical characterizations using the forward and reverse bias $I-V, C-V$ and $G-V$ measurements and were seen that the insulator $\mathrm{Si}_{3} \mathrm{~N}_{4}$ layer influenced characterizations of the contact. Some diode parameters and effect of the interface states $\left(N_{s s}\right)$, the series resistance $\left(R_{s}\right)$ were investigated by calculating from $I-V$ and $C-V$ measurements.

\section{REFERENCES}

Ataseven T, Tatatroğlu A, 2013. Temperature-dependent dielectric properties of $\mathrm{Au} / \mathrm{Si} 3 \mathrm{~N} 4 / \mathrm{n}-\mathrm{Si}$ (metal insulator semiconductor) structures. Chin. Phys. B, 22(11): 117310-1- 117310-6.

Bilkan Ç, Zeyrek S, San SE, Altındal Ş, 2015. A compare of electrical characteristics in $\mathrm{Al} / \mathrm{p}-\mathrm{Si}(\mathrm{MS})$ and $\mathrm{Al} / \mathrm{C} 20 \mathrm{H} 12 / \mathrm{p}$ $\mathrm{Si}$ (MPS) type diodes using current-voltage (I-V) and capacitance-voltage $(\mathrm{C}-\mathrm{V})$ measurements. Materials Science in Semiconductor Processing 32: 137-144.

Bülbül MM, Zeyrek S, 2006. Frequency dependent capacitance and conductance-voltage characteristics of $\mathrm{Al} / \mathrm{Si} 3 \mathrm{~N} 4 / \mathrm{p}-\mathrm{Si}(100)$ MIS diodes. Microelectronic Engineering 83: 2522-2526.

Bülbül MM, Zeyrek S, Altındal Ş, Yüzer H, 2006. On the profile of temperature dependent series resistance in $\mathrm{Al} / \mathrm{Si} 3 \mathrm{~N} 4 / \mathrm{p}$ Si (MIS) Schottky diodes. Microelectronic Engineering 83: 577-581.

Card HC, Rhoderick EH, 1971. E. H. Studies of tunnel MOS diodes I. Interface effects in silicon Schottky diodes. J. Phys. D: Appl. Phys 4:1589-1601.
Cheung SK, Cheung NW, 1986. Extraction of Schottky diode parameters from forward current-voltage characteristics. Appl.Phys.Lett. 49 (2): 85-88.

Demircioglu Ö, Karataş Ş, Yıldırım N, Bakkaloglu ÖF, Türüt A, 2011. Temperature dependent current-voltage and capacitance-voltage characteristics of chromium Schottky contacts formed by electrodeposition technique on n-type $\mathrm{Si}$ Journal of Alloys and Compounds 509: 6433- 6439.

El-Nahass NN, Metwally HS, El-Sayed HEA, Hassanien AM, 2011. Electrical and photovoltaic properties of $\mathrm{FeTPPCl} / \mathrm{p}-\mathrm{Si}$ heterojunction. Synthetic Metals 161: 2253-2258.

Gökçen M, Altuntaş H, Altındal Ş, Özçelik S, 2012. Frequency and voltage dependence of negative capacitance in $\mathrm{Au} /$ $\mathrm{SiO} 2 / \mathrm{n}-\mathrm{GaAs}$ structures. Materials Science in Semiconductor Processing 15: 41-46.

Güllü Ö, Türüt A, 2010. Electrical analysis of organic dye-based MIS Schottky contacts. Microelectronic Engineering 87: 2482-2487.

Güllü Ö, Aydoğan Ş, Türüt A, 2012. High barrier Schottky diode with organic interlayer. Solid State Communications 152: 381-385.

Karataş Ş, Yildirim N, Türüt A, 2013. Electrical properties and interface state energy distributions of $\mathrm{Cr} / \mathrm{n}-\mathrm{Si}$ Schottky barrier diode. Superlattices and Microstructures 64: 483-494.

Korucu D, Duman S, 2015. Frequency and Temperature Dependent Interface States and Series Resistance in $\mathrm{Au} / \mathrm{SiO} 2 / \mathrm{p}-\mathrm{Si}$ (MIS) Diode. Science of advanced materials 7(7): 1291-1297.

Lee J, Uhrmann T, Dimopoulos T, Bruckl H, Fidler J, 2010. TEM Study on Diffusion Process of NiFe Schottky and $\mathrm{MgO}$ / $\mathrm{NiFe}$ Tunneling Diodes for Spin Injection in Silicon. IEEE Transactions on Magnetics 46(6): 2067-2069.

Markvart T, 2000. Solar Electricity, Baffins Lane; John Wiley \& Sons, Chichester, England.

Nasim F, Bhatt AS, 2013. Influence of different metal over-layers on the electrical behaviour of the MIS Schottky diodes. International Journal of Electronics 100 (9): 1228-1239.

Orak I, Toprak M, TürütA, 2014. Illumination impact on the electrical characterizations of an Al/Azure A/p-Si heterojunction. Phys. Scr. 89(115810): 1-5.

Orak I, Ejderha K, Türüt A, 2015. The electrical characterizations and illumination response of $\mathrm{Co} / \mathrm{N}$-type $\mathrm{GaP}$ junction device. Current Applied Physics 15: 1054-1061.

Orak I, Ürel M, Bakan G, Dana A, 2015. Memristive behavior in a junctionless flash memory cell. Applied physics letters 106 (233506):1-5.

Rajesh KR, Menon CS, 2007. Study on the device characteristics of $\mathrm{FePc}$ and $\mathrm{FePcCl}$ organic thin film Schottky diodes: Influence of oxygen and post deposition annealing. Journal of NonCrystalline Solids 353(4): 398-404.

Roul B, Mukundan S, Chandan G, Mohan L, Krupanidhi SB, 2015. Barrier height inhomogeneity in electrical transport characteristics of InGaN/GaN heterostructure interfaces. AIP Advances 5(037130): 1-12.

Sharma GD, Sharma SK, Roy MS, 2004. Photovoltaic properties of Schottky device based on dye sensitized poly (3-phenyl azo methine thiophene) thin film. Thin Solid Films 468(1-2): 208215. 
Sharma SC, Tewari A, 2011. Field emission of electrons from spherical conducting carbon nanotube tip including the effect of image force. Canadian Journal of Physics 89(8): 875-881.

Sönmezoğlu S, Akın S, 2011. The Determination of Series Resistance Parameter of Sb-Doped TiO2/n-Si MIS Structure by Capacitance-Voltage (C-V) Method. AKU-J. Sci. 11(011101): 1-8

Sze SM, Kwok KN, 2006. Physics of Semiconductor Devices, John Wiley \& Sons,Inc, Third edition New Jersey, USA. 832 p.

Sze SM, 1981. Physics of Semiconductor Devices, second Ed. Willey \& Sons, NewYork, USA. 815 p.

Sztkowski J and Sieranski K, 1992. Simple interface-layer model for the nonideal characteristics of the Schottky-barrier diode. Solid State Electron. 35(7): 1013-1015.
Tatar B, Bulgurcuoglu AE, Gokdemir P, Aydogan P, Y1lmazer S, Ozdemir O, Kutlu K, 2009. Electrical and photovoltaic properties of $\mathrm{Cr} / \mathrm{Si}$ Schottky diodesInt. J. Hydrogen Energy 34: 5208- 5212.

Turut A, Karabulut A, Ejderha K, B1yıklı N, 2015. Capacitanceconductance-current-voltage characteristics of atomic layer deposited $\mathrm{Au} / \mathrm{Ti} / \mathrm{Al} 2 \mathrm{O} 3 / \mathrm{n}-\mathrm{GaAs}$ MIS structures. Materials Science in Semiconductor Processing 39: 400-407.

Yahia IS, Farag AAM, Yakuphanoğlu F, Farooq WA 2011. Temperature dependence of electronic parameters of organic Schottky diode based on fluorescein sodium salt. Synthetic Metals 161 (9-10): 881-887.

Zeyrek S, Altındal Ş, Yüzer H, Bülbül MM, 2006. Current transport mechanism in Al/Si3N4/p-Si (MIS) Schottky barrier diodes at low temperatures. Applied Surface Science 252: 2999-3010. 
